Unity Journal

Vol. III, 183-194, 2022

Doi: https://doi.org/10.3126/unityj.v3i01.43324

Prithvi Narayan Shah Research Center

Directorate General of Military Training, Nepali Army

Kathmandu, Nepal

\title{
The Role of Military Diplomacy in Nepal's Foreign Policy
}

\section{Jiwan Paudel}

\begin{abstract}
Military diplomacy is the exploitation of a range of military resources, both bilaterally and multilaterally, to create favorable and cooperative ties with foreign nations in a pacific manner. Mutual security pacts, defense assistance, intelligence sharing, anti-piracy missions, joint military drills, communications assistance, disaster-relief missions, and high-level engagements between senior military hierarchies comprise military diplomacy. Military diplomacy aims to fill in the gaps, when needed, to help its parent nation respond to the challenges and complexity of disruptive, fast changing, strifetorngeopolitical circumstances while working in tandem with other state instruments. Nepal Army's intensive experiences in jungle and

training etc. would strengthen bilateral military relation along with improved foreign policies. The first part of this paper explores the role of Nepalese military diplomacy in Nepal's foreign policy with Britain, India, China and United Nation in various time periods followed by second part focusing on SWOT analysis, possible counsels for better diplomacy and future prospects. This paper is framed with doctrinal methodology wherein primary data were collected from statues, seminar brochures, research and review papers, interview of current and exNepal Army officer and Ministry of defense reports whereas secondary data sources used for the study are legal prodigals, treaties, encyclopedia, newspaper, reports, and bona fide information.
\end{abstract} mountain warfares, tactical operations, and its undoubtable military training exercises have been employed to develop vibrant bilateral relations. The compelling military diplomacy of Nepal Army with foreign nations led to unstinting support and assistance in garnering essentials during the devastating earthquake and COVID-19 situation. Peacekeeping force should be prioritized to enhance foreign policy and seek to direct Foreign Direct Investment to Nepal. Appointment of military attache to the nations having bilateral relations with Nepal, hosting of cultural and sports meet, high altitude

Keywords: Rana regime, Nepal Army, Diplomacy, United Nations, India, China, Britain

\section{Introduction}

The United States, France, the United Kingdom, and NATO countries may perhaps be regarded as world leaders in military diplomacy. China has been expanding its military diplomacy significantly and could be counted among the leaders as well. India and Australia have a significant history of military diplomacy. The Nepal Army's (NA) global profile has gone through the roof over the 
past century, with a noticeable increase in the frequency and intricacy of its engagements with foreign nations. The Nepalese army conducts multilateral meetings and interacts with foreign militaries all across the globe, establishing diplomatic ties, strengthening Nepal's soft power, and learning how to deploy and support military forces for long stretch of time.

Military diplomacy - sounds like a contradiction, isn't it? - is a tool to eliminate international enmity, while creating and perpetuation trust and assurance in partner countries; it also supports structuring armed forces that successfully accomplish the democratic directions of the government. The military normally achieves the nation's objectives with hard power, whereas diplomacy strives to achieve the nation's goals with soft power. (Swistek, G. 2012). Military and political diplomacy seem to be very analogous in appearance, with meetings, discussions, visits, receptions, treaty signings, negotiations, press conferences, diplomatic protocol, participation in international conferences, and the exchange of diplomatic documents being the most common events. However, in the case of military diplomacy, the content is chiefly military in nature, troops are tangled, military collaboration is solid, military strength is exploited to demonstrate sovereign power, and it is characterized by better dignity, formality, and solemnity. Military/defense diplomacy strives to achieve national security as well as the parent country's foreign policy goals. Military diplomacy covers elements like mutual security pacts, defense assistance, intelligence sharing, anti-piracy missions, joint military drills, communications assistance, disaster-relief missions, and highlevel engagements between senior military hierarchies.
King Prithvi Narayan Shah is regarded as the pioneer of military diplomacy in Nepal's history when he made alliances with newly formed Baise and Chaubise states in 1743 in order to strengthen his military capability and to safeguard Nepal from foreign invasion (Lamsal, 2016). His diplomatic policy led to the amalgamation of 54 newly formed states into Nepal as a unified, sovereign, independent Himalayan nation with warriors soon after taking control over Kathmandu in 1769. Shah was clever enough to formulate his strategy to use hard power against smaller and weak states to incorporate them to form Nepal; however, he uphold a defensive and protective narrative in regard to stronger, clever, well equipped northern and southern neighbors and come into war if and only it was inevitable. After the setback on the Anglo-Nepal War (1814-1816), that led Nepal to surrendered one-third of its land to the Britishers, the Rana regime (1846-1950) framed a foreign policy grounded on geostrategic separation, which bestowed Nepal comparative liberty from foreign intrusion and command. Military diplomacy has long been practiced in Nepal, British acknowledge Nepal as a sovereign nation because of its aid to the British East India Company to overturn the Sepoy Mutiny and fighting in two world wars. The involvement of military in strengthening the nation's foreign policy has been evident throughout history. Employment of military as an institution that could play a primary role in foreign policy is a principal act for economically poor country like Nepal.

In this paper, I take the approach of demonstrating how military diplomacy evolved in Nepal during 1700 AD followed by its gradual implementation to preserve national security, integrity, sovereignty and global imaging. I shall also recommend some possible changes on existing military 
diplomacy tools and techniques for their efficient role to bolster foreign policies.

\section{Military Diplomacy and Foreign Policy}

\section{During 1750 to 1949 A.D.}

Having established as a nation now it was time for Nepal to demonstrate its foreign policy tactics to preserve its sovereignty and to safeguard the national territory for which various military tactics like wars, trainings, meetings were held. The result of such tactics in various durations that bolstered Nepal's foreign policy are discussed in this section. Nepal's thirst to expand its northern territory followed by dispute over trans Himalayan trade and currency led to cold relationship with Tibet resulting in Nepal-Tibet war of 1788. NA reached Shekar Dzong and Dzongkha two tactical cities situated in Tibet after they conquered Tibet in 1788. Shulien, the Chinese residents of Tibet at that time, reported the incident to the Chinese Emperor, who without any doubt dispatched the Chinese troops towards Tibet for hindering the progress of NA. Finally, on 1789 the war was placated between Nepal and Tibet after reaching an agreement which put end to the war. Nepal took an opportunity to establish and strengthen political as well as military ties with Tibet and China after which Nepal started sending a Naikya to Lhasa, Tibet, on the military front. But the pacific situation did not last long as Tibet broke some points of the 1789 agreement which finally led to another war in 1791-1792. NA attacked Tibetan army in the city of Dirgacha-Tibet after which the latter were forced to step down. A treaty with Tibet signed on October 5, $1792 \mathrm{Nepal}$ and Tibet signed a contract entrusting China in resolving future disputes between Nepal and Tibet, which also set a foundation for Nepal-China military cooperation. Nepal and
China pledged in the treaty that "if Nepal is ever attacked by a foreign force, China will not hesitate to assist her." The third battle between Nepal and Tibet broke out in March 1855 after Tibet disregarded Nepal's ambition to restore the land won in the 1791-1792 war, as well as trade-related concerns, under the 1792 treaty. After NA got victory on battle, the war was terminated with another Treaty signed on March 24, 1856 (Jain, 1980).

Jung Bahadur sensed the golden opportunity to establish military diplomacy with British India during the Sepoy Mutiny on 1857 which is often regarded as the first revolution for independence of India (Worden, 1993). At the time, the rebels were able to seize control of Bengal's major towns. The news of the Sepoy Mutiny entered Kathmandu in midMay 1857 soon after which Jung Bahadur planned to take advantage of the situation to establish good neighborly relations with the British. The Nepali administration was at high alert, and the first deployment for the mission was dispatched to Lucknow in June 1857, followed by two additional detachments. Jung Bahadur himself led 8,000 Nepalese soldiers into India on December 10, 1857. Jung Bahadur, who commanded 15,000 Nepalese warriors as a whole, backed the British campaigns located at Lucknow and Gorakhpur. The NA performed well, which led the capture of Lucknow after which the Prime Minister returned gloriously back to Nepal in March 1858, but kept on supporting the British by eliminating the rebels hiding in the Terai of the Nepal-India border to save their lives. Britishers were elated with the support and backing of Nepalese troops; they decided to reward Nepal for its service as Jung Bahadur had expected (Shrestha, 2011). A treaty between Nepal and the British Government was concluded in November 
1860 which enabled Nepal build better ties with the British and reclaim its territory lost to Britishers during the Anglo-Nepal War. Furthermore, it persuaded the rulers that by continuing to assist the British, Nepal would prosper (Leo, 1971).

During World War I (1914-1918), Nepal again supported British India by deploying ten battalions of Nepal Army to reinforce British and Indian troops fighting abroad. A total of 55,000 Nepalese youths were also recruited into new, fresh and innovative battalions. Many of Nepali warriors fought in the European and Middle Eastern regions during the war, including in the 1919 Waziristan operation in Afghanistan (E. Rose \& Leo 1971). Nepal suffered a significant casualty of its 20,000 comrades among the 200,000 troops who participated in war supporting Britishers. The British accolated the bravery depicted by Nepali warriors because of which The then Prime Minister Chandra Shamsher was made a "honorary general" in the British forces and was given the "Honorary Knight's Cross of St. Michael and St. George" by the British, calling him as "His Highness." Nepal also got a gift of one million rupees per annum by Viceroy Lord Canning. The Nepal-Britain Treaty of 1923 was the most significant reward for Nepal, as it honored the Rana regime's military assistance to the British during World War I. The treaty, inked on December 21, 1923, was a watershed moment in Nepalese diplomacy since it acknowledged Nepal's sovereignty and gave it the freedom to explore and practice its foreign policy as it finds appropriate (Valley, 2009).

During World War II, the Rana regime's massive military-diplomatic assistance for the British was considerably greater than that extended to them during World War I. When the conflict broke out, ten battalions of the NA landed in India and were assigned to fortress duties till the war ended. During World War II, the British again expected Gurkhas to fight internationally, and the Nepal government agreed (Rathaur, 2001). The consolidated alliance with the British garnered significant financial and military assistance from the British. The Ranas also permitted the British to enroll Gurkha battalions into British military divisions, as well as a massive number of Nepalese for Indian military units like as the Assam Rifles, Burma Rifles and Kashmir Infantry . Prime Minister Juddha Shamsher, like his forefathers, did everything possible to assist the British authority by providing sufficient numbers of soldiers. The overall number of Gurkha soldiers in various recruiting centers surpassed 200,000 for service in all zones, including Middle East, Burma and North Africa. Nepali soldiers suffered 32,000 casualties during the second world war after which the British, Nepal, and India signed on a tripartite treaty in November 1947 that enabled the enrollment of Gurkhas in Britain and India to continue for eternal. India could not organize Gurkhas against "Hindus," "disarmed mobs," or "the Gurkhas itself," according to the treaty (Savada, 1991). India's request to help them during 1947 violence in order to preserve law and order gave further blossom to Indo-Nepal friendship (Subedi, 2005). The violence was the result of partition of British India into India and Pakistan which culminated into bloodshed at several locations. On India's request Nepal sent detachment of 19 battalions commanded by a major general at the places of conflict to assist pacify the scenario and maintain peace.

\section{From 1950 to 1990 A.D.}

The Mahakali (river) Treaty formally came to an end after the Treaty of Peace 
and Friendship which was based on IndoNepal boundary was signed between Nepal and India in 1950. The Nepali and Indian militaries have had a nearly seven-decade long tradition of conferring the honorary rank of general in the NA to the Indian Army and vice versa. This practice started back during the Rana administration in 1950, when Indian Army Chief General K. M. Cariappa visited Nepal. Even when political ties were at a low point at times, the two forces maintain friendly, cordial, formal relationship as evinced by the interchange of army heads' visits and contacts. The newly appointed Chef of NA lands in Delhi after taking his roles and responsibility as a tradition to make India a first destination after in charge of NA. This cultural action helps to maintain diplomatic relationship with India. The honorary general also pays a formal visit to the president, prime minister, and defense minister during his visit to address bilateral matters. India had established posts on Nepal's northern border under the friendship treaty by 1954 , this stance brought Nepal directly into India's security sphere and was criticized by the general public for the assumed role of spy across the northern border (Rose Leo, 1980). Amid such criticism after 17 years the Indian mission withdrew in August 1969 through a formal agreement, between Nepal and India. Such success in successful withdrawal of the Indian mission without any enmity marked a significant positive shift in the foreign policy of Nepal and paved the way for the variety of foreign policy options available to achieve Nepal's national interests away from India as well (E Rose Bhuwan L Joshi \& Leo, 1966).

The successful disarming operation against the Khampas in 1974 was another significant achievement by Nepal's military diplomacy as it contributed to the promotion of Nepal-China bilateral relationship by honoring Nepal's "One China” policy. But unfortunately, this support to China did not go down well with India. The Khampas were the fighters of a militant group that stood against China's occupation of Tibet from 1950 and until until 1974 fighting for their freedom. When the Dalai Lama made an escaped to India in 1959, China's intense military operations forced some Khampas to take refuge in the northern Himalayan border of Nepal. Khampas were accused of carrying out anti-China activities from within the Nepalese territory which were against Nepalese foreign policy, which adheres to a "One China" policy. China very aware of the Khampas rebellion and their actions requested Nepal to support them in order to control and disarm them. NA took this opportunity and disarmed the rebels and surrendered them in front of Chinese military. With this military support to China, not only Nepal pleased China and strengthen the China-Nepal friendship, but it also stopped Chinese troops from entering Nepalese territory to operate against the Khampas, thereby preserving the territorial integrity of Nepal.

Examining relations between Nepal and the United States in the 20th and 21st centuries demonstrate power relations in three distinct areas: strategic or military interests, political interests, and economic power. With respect to security interests, in the geopolitical context of the 1950s, aid from the United States successfully and indirectly helped Nepal to maintain its independence (Khadka, 1993, p. 90). Nepal's former Foreign Secretary Y.N. Khanal (1973) noted "Nepal's relations with the United States have helped to maintain a balance in its friendly relations with India and China."However, after the mid-1960s when the US deemphasized its strategic interests 
in Nepal, it is difficult to attribute Nepal's success in maintaining its independence and neutrality to US aid programs. Since the 1970s, Nepal has received aid as part of a US global policy, offered with general objectives and guidance.

\section{From 1991 to 2021 A.D.}

The U.S. Pacific Command and NA has cohosted The Shanti Prayas (Peace Initiative) Exercise, three times in 2000, 2013, and 2017 (Mohr, 2017). Initially there were only 4 participating nations when it was started in 2000 but the number rose significantly to 23 and soldiers to 445 by 2013 moreover, 34 nations with 1068 soldiers participated in 2017 (Kantipur, 2013). Such overwhelming participation of foreign nations demonstrates the high level of professionalism of NA and its aim to extend military diplomacy with multiple foreign nations; however, NA must coordinate with Ministry of Defense (MoD), Ministry of Foreign Affairs (MoFA), and in line with the foreign policy of Nepal for effectiveness of the mission. Joint military exercises like these not just strengthens capability of Nepal Army but also bolsters Nepal's diplomacy with the participating nations (THT Online, 2017). After 1990 and before $2000 \mathrm{Nepal}$ was not having substantial military cooperation with China; however, since the beginning of the 21 st century particularly after the constitution assembly elections in 2008, the diplomacy between the militaries of Nepal and China grew by many folds. During 2001-05 Nepal largely acquired defensive gears from the India, United States, and the United Kingdom when the NA was fighting against the Maoist insurgency (Bhattarai, 2019). Although it wasn't all evident; India was supposed to have assisted materially and morally to Maoists (as revealed by the Siliguri meeting in August 2001) however India decleared the Maoists as terrorist groups a month after in September 2001, while increasing military aid to the Nepali Army, demonstrating the ad hoc nature of Indian foreign policy to Nepal which illustrates India's muddled Nepal policy (Manhas \& Sharma, 2014).

However, after King Gyanendra's royal coup in 2005 halted the military assistance from such nations. During this harsh time, when the NA was lacking on defense supplies, China bestowed Nepal with military assistance worth $\$ 1$ million to combat the intruders. Following China's initial backing, the defense agreement struck between Nepal and China in December 2008 was noteworthy in that China pledged to help modernise the NA with USD 2.6 million in aid and prepared the path for high-level military and civilian personnel to visit Nepal. (Adhikari, 2018). Again in December 2009, China agreed to assist Nepal army with the supply of "non-lethal" hardware that includes logistics and training. The handover memorandum was signed by head of the visiting Chinese team Maj. General Jia Jialing, and Toran Jung Bahadur Singh, the acting chief of the Nepalese Army, At the Nepal Army HeadQuarters (Bhattarai, 2019).

During the 2015 covert economic blockade, when politicians in Nepal and India were at odds, the NA and Indian Army's militarydiplomatic relationship played a vital appeasing role (Pant, 2018). When Nepal had just recovered from the 7.8-magnitude earthquake on April 25, it was hammered severely by an unofficial Indian economic embargo on September 20, bringing the country alarmingly near to a humanitarian catastrophe. During this period of political turbulence, CoAS General Chhetri was invited to India for almost a week long formal 
tour to earn the honorary title of CoAS of the Indian Army. Though the visit was difficult to schedule given the impact of the embargo on Nepalese citizens, it provided a chance to meet with India's multiple power structures and persuade them to relieve economic and transit issues while also reinforcing the Nepal and Indian bond (Pattisson, 2015). The Chiefs of Army of both nations were instrumental in correcting the Indian elite's erroneous perceptions and relieving the embargo. India removed the embargo a day before General Chhetri's tour ended, much to the delight of many Nepalese. As a result, the NA, Nepal's oldest organization, demonstrated its ability and efficiency in successfully carrying out military diplomacy (Anonymous, 2016).

During the economic embargo, the Nepalese government was obligated to be inclined towards China to disrupt India's monopoly on trade and transit. Following that, the K.P. Sharma Oli administration embarked on a major phase of defense ties with the Dragon. According to reports, China has agreed to establish a Defense University in Nepal. The first ever joint drill between Nepal and China, "Sagarmatha Friendship-1," was organized in Kathmandu in April 2017, while the second military exercise, "Sagarmatha Friendship-2," was conducted in Chengdu, Sichuan Province, China, in September 2018. Military personnel are encouraged to express their expertise and experiences with their compatriots through this form of training (Subedi, 2018).

NA has proved its equality with both Nepal's major neighbors by conducting training operations with India and China as equivalent sovereign states. Nepal meets with highest military and civil defense officials from both nations, discusses defense collaborations on a bilateral and multilateral basis, and participates in training and exchanges of military and civilian defense professionals. However, Nepal's last-minute pullout from BIMSTEC military drill, which was conducted by India, doesn't really serve the objective of calibrated military diplomacy because it has further exacerbated the trust gap between India and Nepal.

One of the largest humanitarian and catastrophe response missions of the year was the global effort to the 7.8 magnitude earthquake that hit central Nepal at noon on April 25, 2015. The Nepalese government sent a plea for foreign assistance around 3 to 4 hours after the earthquake, and 34 nations complied. This resulted in 76 Urban Relief and Recovery (USAR) teams with 2,242 individuals and 135 K-9 dogs, 141 Foreign Medical Teams (FMT) with 1,858 health personals, and 18 overseas military squads in total (Naresh Subba, 2015). Engineers, aerial support manpower, health professionals, and relief and recovery experts from Algeria, Bhutan, China, Bangladesh, Canada, India, Indonesia, Israel, Japan, Malaysia, Engineers, aerial support manpower, health professionals, and relief and recovery experts from Algeria, Indonesia, Bhutan, China, Bangladesh, Canada, India, Malaysia, Israel, Japan. With its teams coming after the first 12 hours, India was the very first international team to react. Following that, squads from Nepal's neighbors Bangladesh, China, Bangladesh, Sri Lanka and Bhutan took part. Again within 72 hours, squads from 14 other nations (a total of 1966 persons) landed in Nepal whereas the remainder teams arrived within the first week of cataclysm ((Humanitarian Civil-Military Coordination, 2015)). 


\section{SWOT analysis of Military Diplomacy in Nepal's foreign policy}

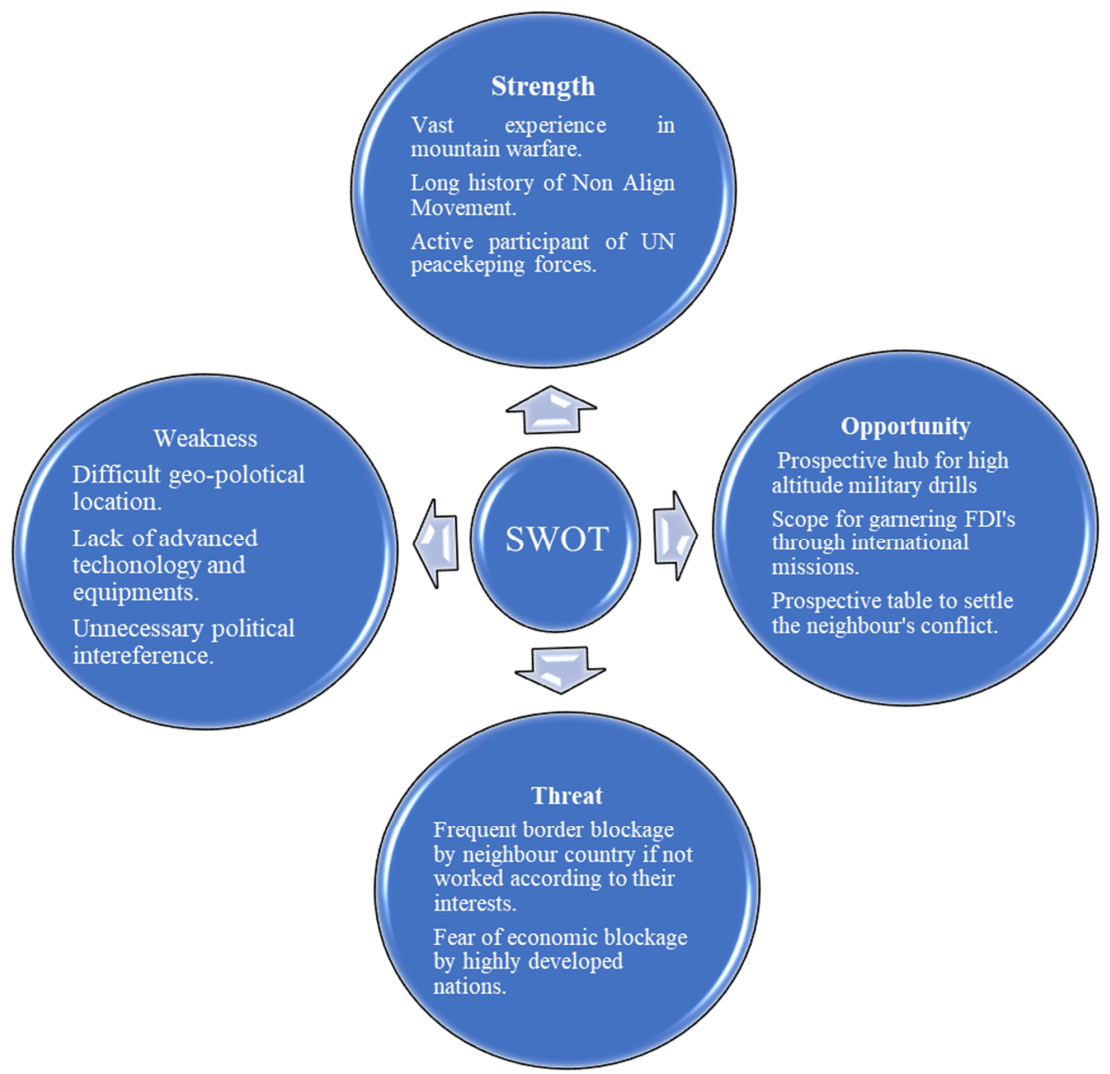

\section{Recommendations}

Based on the issues aforementioned in the paper, the following statements are being recommended for betterment of military diplomacy to ameliorate Nepal's foreign policy.

The dearth of Nepal's country-specific foreign policy, based on our broad national interest, is very unfortunate. Nepal should begin formulating the country-specific foreign policy for major and important countries through joint military engagement where possible and exercise diplomacy accordingly. Military diplomacy must be blended with foreign policy outreach.
The constitution of Nepal has bound the rights to introduce the new foreign policy. We are only set free to adjust and prioritize the issues in line within the parameters as defined by the Article 50 and 51 of the Constitution of Nepal. A sound military diplomacy doctrine is to be formulated based on Nepal's foreign policy in order to abide the unsuccessful balancing act - 2015 blockade imposed by India on Nepal- and diplomatic setbacks resulting from last minute recession of Nepal from BIMSTEC.

The Nepal Army should try to generate a fairly amicable and assured environment for Foreign Direct Investment (FDI) in ample areas of Nepal including agriculture, 
hydropower, construction, industrial, tourism services, manufacturing, minerals, and energy. So, there is the pressing need for solid work to promote economic diplomacy of Nepal, having an abundance of resources at its disposal.

The Nepali Army need to take the lead on the interagency coordination with Nepal Police and Armed Police Force, improve its supply chain management, focus on improved training and equipment for better mission performance, as demanded by the secretary general's action for peacekeeping initiative, and increase opportunities for participation in the UN peacekeeping by pledging for high-value niche capabilities such as aviation, engineers, logistics, signals and transportation. The use of technology makes the peacekeeper smarter. For all this, Nepali Army should develop a Peacekeeping Strategy, which complements diplomacy, and is in accordance with the government policy and national interest.

UN peacekeeping is not just the responsibility of the NA; the Government of Nepal must make considerable attempts to use peacekeeping as an instrument of foreign policy and to retain Nepal's weight in UN matters. One area where NA has played a big role in assisting Nepal's foreign policy is UN peacekeeping. As a result, Nepal's foreign policy and military diplomacy should be more closely aligned in the framework of UN peacekeeping in order to reclaim its nonpermanent member position in the UNSC and obtain larger stature in international affairs in terms of Nepal's national interests.

\section{Conclusion}

The glorious history of Nepal Army despite the thick and thins of Nepal's government has always been a pivotal tool in fostering Nepal's foreign policy. Beside maintaining peace, preserving sovereignty, enhancing national integrity, the NA always stood for the interest of Nepal in the international community as well. This study found the trend of Nepal's military diplomacy during various time frames with different nations. The NA always gave its best to enhance Nepal's image globally through joint drills, intelligence sharing, high level engagements, mutual understanding, formal high level visits etc. The Nepal army although an old institution has always tried to frame its diplomacy in a very contemporary manner. Despite being an effective tool some major changes are expected in regard with the appointment of military attache to nations having diplomatic relation with Nepal, hosting of cultural and sports meet, high altitude training etc.

\section{Future Prospects}

The Nepal Army's leadership must develop a culture of strategic thinking, for though the army has for the past 250 years successfully upheld the territorial integrity of Nepal at great sacrifice to itself, it is now finding itself on the wrong side of history. It is certain that even after the integration issue is resolved, the army's role and function, its loyalty and its ability to curb militancy and terrorism will continue to be key issues of a new Nepal and, therefore, it would remain a critical institution of the country in the foreseeable future. Nepal's increasing vulnerabilities on the domestic front; changing bilateral relations between its two closest neighbors', India and China, from competition to co-operation; and the shift of the global political order from confrontation to co-operation since the end of Cold War. Human security issues have become more prominent, posing more serious challenges to the stability, progress 
and prosperity of Nepal than traditional, statecentric threats. At the United Nations mission the NA is using the doctrine that is basically prepared by focusing on the traditional mission. So, it is essential to change the doctrine of peacekeeping missions in a wider perspective to address the mechanism of operating in multi-dimension missions. Nepal army should take multidisciplinary country wise diplomatic approaches in strengthening military ties and relationships to enhance Nepal's foreign policy.

\section{Reference}

Adhikari , D. R . (2018). A Small State between Two Major Powers: Nepal's Foreign Policy Since 1816. Journal of International Affairs, 2(1), 43-74. https://doi.org/10.3126/joia. v2i1.22575

Agrawal, R. (2015, April 27). Nepal earthquake: India leads massive aid effort to help survivors. CNN. https://edition.cnn.com/2015/04/27/ asia/nepal-quake-india-aid/index.html

Humanitarian Civil-Military Coordination. (2015, May 30). Humanitarian Civil-Military Coordination in the Nepal Earthquake response. Office for the Coordination of Humanitarian Affairs. https://reliefweb.int/ report/world/humanitarian-civil-militarycoordination-asia-pacific-newsletter-issue-5may-june-2015

Anonymous. (2016, February 16). Camaraderie between Nepal Army \& Indian Army ended blockade, not politicians. Southasia. https://www.southasia.com.au/2016/02/19/ camaraderie-between-nepal-army-indianarmy-ended-blockade-not-politicians/

Bhatarai, K. D. (2019, May 19). A brief history of Nepal-China defense ties. The Annapurna Exprress. https://theannapurnaexpress.com/ news/a-brief-history-of-nepal-china-defenseties- 1560
Bhattarai, K. (2019). A briefhistory of Nepal-China defense ties. https://theannapurnaexpress. com/news/a-brief-history-of-nepal-chinadefense-ties- 1560

Hodal, K. (2019). UN peacekeepers intervene after violent clashes in South Sudan. The Guardian. https://www.theguardian.com/ global-development/2019/dec/06/unpeacekeepers-intervene-after-violent-clashesin-south-sudan

Jain, R. (1980). China South Asian Relations, 1947- 1980. NJ: Humanities Press, 2, 19501980.

Kantipur. (2013, March 13). Military Diplomacy. Editorial, Kantipur National Daily.

Lamsal, Y. N. (2016). Unification Era Diplomacy. The Rising Nepal.

Leo, R. (1971). Nepal's Strategy for Survival. Berkeley: University of California Press.

Lohani, M. P., \& Thapa, D. B. (1996). Nepal and the United Nations. Kathmandu: United Nations Association of Nepal. https://franklin.library.upenn.edu/catalog/ FRANKLIN_9926377583503681

Manhas, N., \& Sharma, M. (2014). The 1950 Treaty of Peace \& Friendship: An Issue of Contention between India and Nepal. International Journal of Scientific and Research Publications, 4(11).

Mohr, T. (2017). Shanti Prayas Exercise Commences in Nepal. U.S. Department of Defense News. https://dod.defense.gov/ News/Article/Article/1124708/shanti-prayasexercise-commences-in-nepal

Pant, B. (2018). Socio economic impact of undeclared blockade of India on Nepal. Research Nepal Journal of Development Studies, 1(1), 18-27. https://doi.org/10.3126/ rnjds.v1i1.21270 
Pattisson, P. (2015). Nepal border blockade "threatens the future of the country itself", says UN. The Guardian. https://www.theguardian. com/global-development/2015/nov/18/nepalborder-blockade-india-threatens-future-ununicef

Rathaur, K. R. S. (2001). British Gurkha Recruitment: A Historical Perspective. Voice of History, Vol. XV(2).

Rose, E., Joshi, B. L., \& Leo. (1966). Democratic Innovations in Nepal A Case Study of Political Acculturation. Berkeley: University of California Press.

Rose, E., \& Leo. (1971). Nepal: Strategy for Survival. California Press Berkeley, Los Angeles,London.

Rose, L., \& Scholz, J. (1980). Nepal: Profile of a Himalaya Kingdom. Boulder, CO: Westview Press.

Savada, A. M. (1991). Nepal and Bhutan Country Studies. Washington, D.C.: Federal Research Division, Library of Congress.

Shrestha, R. (2011). Boundary Treaty - 1st November 1860. Complete Nepal Wordpress.

Subba, N. (2015). Nepal Earthquake 2015 Nepalese Army Experience and Lessons Learnt. https://dms.nasc.org.np/sites/default/ files/documents/Col.NareshSubba.pdf
Subedi, R. R. (2018). Nepal-China defense cooperation builds on momentum. China.Org.Cn. http://www.china.org.cn/ opinion/2018-11/16/content_72867570.htm

Subedi, S. P. (2005). Dynamics of Foreign Policy and Law: A Study of Indo-Nepal Relations. Oxford University Press.

Swistek, G. (2012). The Nexus between public diplomacy and military diplomacy in foreign affairs and defense policy. Connections, 11(2), 79-86.

THT Online. (2017, April 3). Exercise Shanti Prayas III concludes. The Himalayan Times. https://thehimalayantimes.com/nepal/ exercise-shanti-prayas-iii-concludes

Valley, P. (2009). The Big Question: Who Are the Gurkhas and What Is Their Contribution to Military History." The Independent. https:// www.independent.co.uk/news/uk/homenews/the-bigquestion-who-are-the-gurkhasand-what-is-their-contribution-to-militaryhistory-1676354.html

Worden, R. L. (1993). Nepal and Bhutan: Country Studies, Issue 46. Washington, D.C.: Federal Research Division, Library of Congress. https://books.google.com/ books?id=61CdRT 8 NCpUC\&pgis $=1$ 